\title{
THE IMPACT OF TRAFFIC DYNAMIC ON AIR QUALITY AND VULNERABLE OBJECTS NEAR BUSY STREET IN NOVI SAD
}

\author{
UDC 502.3:711.4(497.11NOVI SAD)
}

\section{Bogdana Vujić, Una Marčeta}

\author{
University of Novi Sad, Technical Faculty "Mihajlo Pupin“, Zrenjanin, Serbia
}

\begin{abstract}
In this paper, the distribution of nitrogen dioxide originating from vehicles from a busy street in Novi Sad, located near residential buildings and kindergartens, was performed. Based on the calculated level of nitrogen dioxide emissions from the vehicle, as well as the most frequent meteorological conditions, simulation of nitrogen dioxide propagation was carried out using ADMS urban software. Considering that the street is a part of the bridge whose elevation is gradually increasing, this research reveals permanently and intense exposure of certain parts of the residential buildings. The results presented in this paper can serve as a useful basis for taking measures to reduce the impact of traffic on air quality and human health through urban planning particulary of vulnerable facilities.
\end{abstract}

Key words: urban areas, air quality, modeling of pollutant emission from traffic

\section{INTRODUCTION}

Air pollution in urban areas is a consequence of various human activities carried out daily to meet their needs. Emissions caused by vehicles [1], environmental structure and microclimate conditions that are specific for every environment affect air quality in urban areas to a considerable extent [2].

Due to the increased number of vehicles, large cities are often faced with very high concentrations of pollutants causing negative effects on human health, vegetation, material goods and global warming. Among others, the most important pollutants in urban environments are nitrogen oxides $\left(\mathrm{NO} / \mathrm{NO}_{2} / \mathrm{NO}_{\mathrm{X}}\right)$. It is estimated that even $41 \%$ of the NOx emission originates from traffic [3]. Permanent exposure to nitrogen oxides causes different adverse effects on the health. It is determined that $90 \%$ of the total NOx amount is absorbed into bodies through the respiratory system causing nose and throat irritation in

Received January 18, 2018 / Accepted April 13, 2018

Corresponding author: Bogdana Vujić

University of Novi Sad, Technical Faculty "Mihajlo Pupin“, Đure Đakovića bb, 23101 Zrenjanin, Serbia

E-mail: bogdana.vujic@tfzr.rs 
low concentrations, while asthma and cardiovascular diseases caused by methemoglobin in high concentrations [4].

There are different approaches with the goal to reduce the air pollution in urban areas originating from traffic. These approaches cover the requirement for the fuel quality [5], planning and construction plan [6,7], traffic management, green areas and vegetation expansions that contribute to the mitigation of the negative effects $[8,9,10,11]$.

For protecting the health, limit values (LV) are set for $\mathrm{NO}_{2}$ at different time scales. Table 1 shows the $\mathrm{NO}_{2}$ limit values according to the legislation of the Republic of Serbia (RS) [12], as recommended by the World Health Organization (WHO) [13] of the United States Environmental Protection Agency (USEPA) [14].

Table 1 Ambiental air limit values for $\mathrm{NO}_{2}$

\begin{tabular}{lccc}
\hline & RS & WHO & USEPA \\
\hline GV (1h) & $150 \mu / \mathrm{m}^{3}$ & $200 \mu / \mathrm{m}^{3}$ & $100 \mathrm{ppb}$ \\
& (not to be exceeded more than & & \\
& 18 times in any calendar year) & & - \\
GV (24h) & $85 \mu / \mathrm{m}^{3}$ & - & $53 \mathrm{ppb}$ \\
GV (godina) & $40 \mu / \mathrm{m}^{3}$ & $40 \mu / \mathrm{m}^{3}$ & . \\
\hline
\end{tabular}

Although we are aware of the dominant sources of nitrogen oxides, daily habits and modern lifestyles inevitably lead to the permanent exposure to pollution. Because traffic represents one of the most dominant sources that influence the environment and human health, this paper evaluates the $\mathrm{NO}_{2}$ dispersion from the busy traffic road in Novi Sad, as well as the potential vulnerability of children during the period spent in the yard where they are directly exposed to this pollutant.

\section{MATERIAL AND METHODS}

\subsection{Research Area}

The segment of the road that is the subject of research is in Novi Sad and it is the largest bridge across the Danube connecting the central part of the city with the surrounding places. Also, it is the main road route to Srem, Mačva, Bosnia and Herzegovina and Croatia (Figure 1).

\subsection{ADMS urban}

The simulation was carried out using The Atmospheric Dispersion Modelling System software (ADMS) which is developed by the consulting company "Cambridge Environmental Experts Consultants" (CERC). ADMS is one of the widely used Gaussian dispersion model which simulate a wide range of pollution from various sources [15].

\subsection{Meteorological data}

Data for air dispersion modelling include two sets of meteorological data:1) Required parameters: wind speed $(\mathrm{m} / \mathrm{s})$, wind direction $\left(^{\circ}\right)$ and parameters related to the sensitive surface flux: year/day/time/cloud cover or surface flux (W/m2); 2) Additional meteorological data: boundary layer height $(\mathrm{m})$, surface temperature $\left({ }^{\circ} \mathrm{C}\right)$, lateral spread $\left({ }^{\circ}\right)$, relative humidity $(\%)$ 
The meteorological parameters used in this paper are: wind speed and direction, cloudiness and temperature.

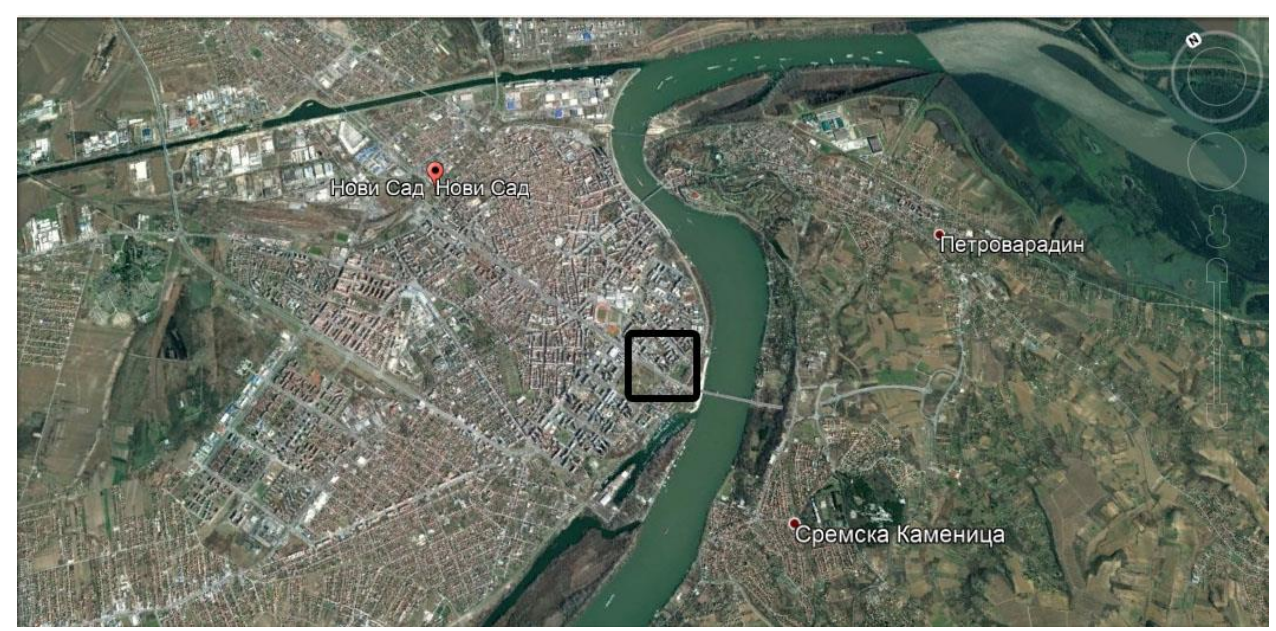

Fig. 1 Research area

\subsection{Traffic emission}

Precise definition of the traffic impact on the air quality and population exposure is conditioned by precise defining of the amount of emitted pollutants, which in this case depends on the flow and characteristics of the present vehicles.

Vehicle emission calculation was performed using the ADMS urban software that calculates emission factors for a defined set of pollutants based on vehicle flow and fleet composition.

\section{RESULTS AND DISCUSSION}

The process of obtaining results using the ADMS urban software package includes several stages:

\subsection{Simulation of real environment used for modelling}

Using the ADMS Mapper program, the segment of the road for which the analysis was performed was graphically presented, thus creating the real environment of the simulation areas. The bridge itself begins at a busy crossroad in a residential part of Novi Sad, gradually rising alongside a residential area consisting of multi-storey buildings on the left and green surface (park) on the left side of the road. Then, the road rises above a recreational zone (football pitch, quay and beach Štrand) and it crosses the Danube river. To achieve the effect of gradual elevation of the road within the research area of $\mathrm{NO}_{2}$ dispersion simulation, the road itself is presented as three-line sources (Source 1, Source 2 and Source 3), with different heights $(0-10 \mathrm{~m})$ from the ground level (Figure 2). 


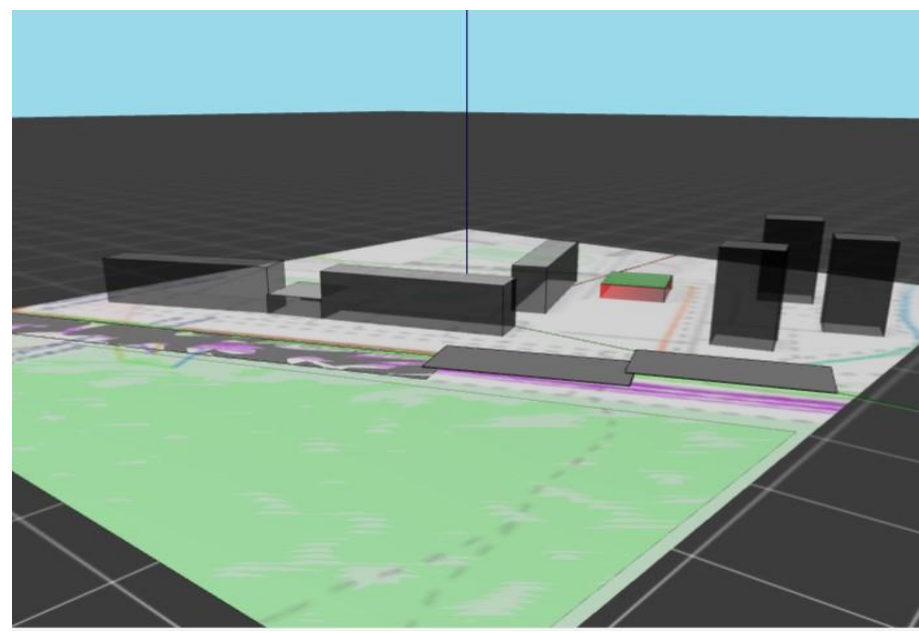

Fig. 2 Simulation of real environment used for modelling

\subsection{Calculation of the vehicle emission level}

The problem of the busy road is relatively even during a day with a short-term flow increase in early morning hours (6 a.m.), as well as in the afternoon hours (from 2 p.m. to 3 p.m.) (Figure 3). Heavy vehicle traffic is prohibited in the defined direction, so the emission factors are calculated for passenger vehicles and for the public city and intercity transportation vehicles. To calculate the emission level, the flow rate data was used at interval from 2 p.m. to 3 p.m.

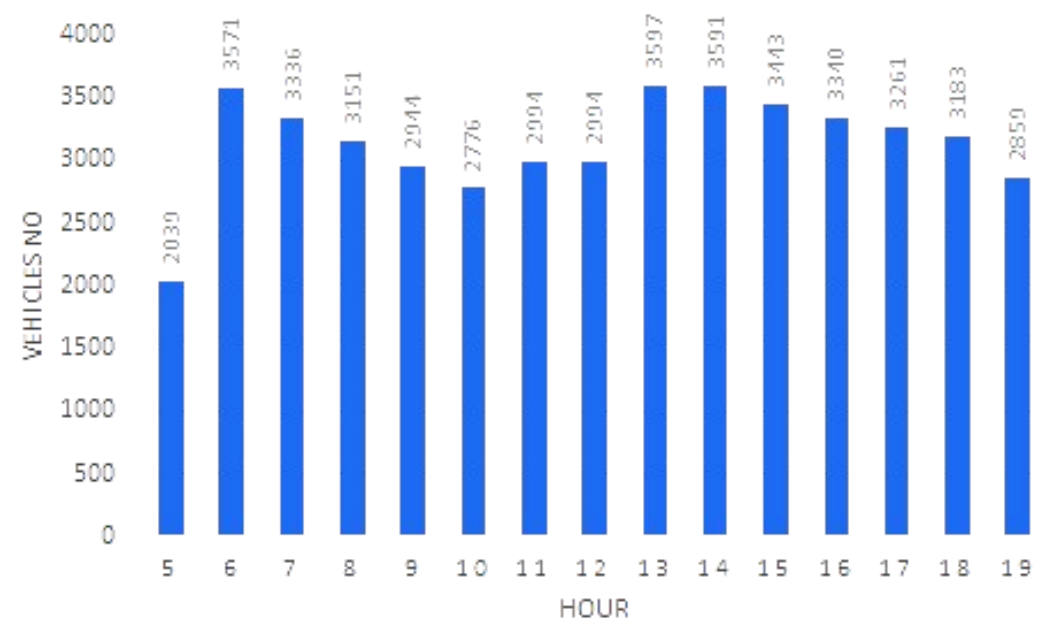

Fig. 3 Vehicle flow on a defined road section [16] 


\subsection{Analysis of meteorological data}

Given the fact that the aim is to estimate the pollutant impact on the air quality and children from the nearby kindergarten during the period spent in the yard and with the goal to select the most representative meteorological data, several facts and assumptions were first considered:

1. The period of spending time in the yard is from 10 a.m. to 12 a.m. and from 2 p.m. to 4 p.m.

2. Children stay in the yard when meteorological conditions are suitable (low wind speed, no rain and relatively pleasant temperature).

3. Periods of the year when children often spend time in the yard is during the spring (April, May) and summer months, not including the summer holiday break (June, July)

Accordingly, an analysis of meteorological data for Novi Sad for 2016 was carried out for the wind (speed and direction) and cloudiness during the spring and summer period [17] at the interval from 2 p.m. to 4 p.m. when the traffic is the most intense.

Wind roses for the given months (for the period from 2 p.m. to 4 p.m.) are shown in Figures 4-7. The wind speed during the observed period ranged from 0.8 to $9 \mathrm{~m} / \mathrm{s}$. However, given that relatively calm period is a period without any wind, a minimum wind speed of $1 \mathrm{~m} / \mathrm{s}$ was considered and that is a value that the ADMS urban software package recognized as "silence".

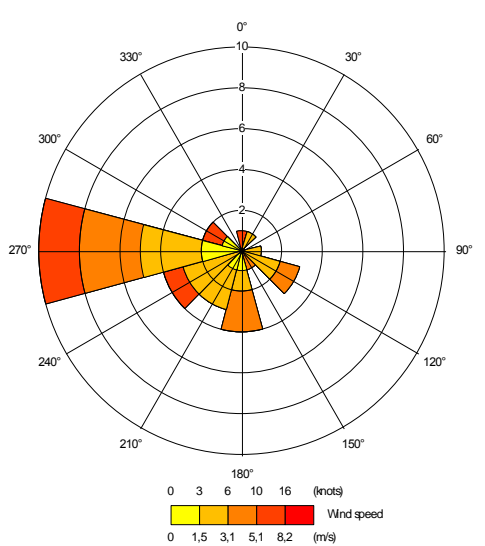

Fig. 4 Wind rose - April

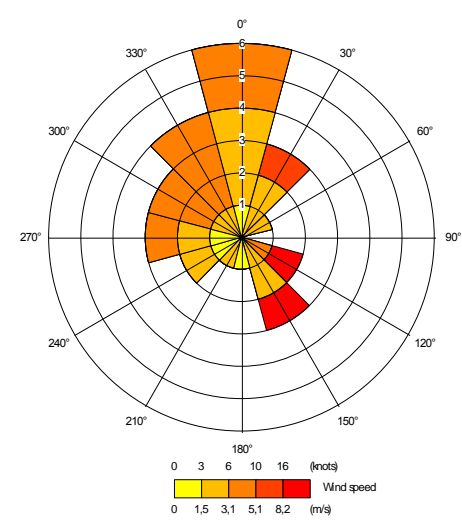

Fig. 5 Wind rose - Maj 


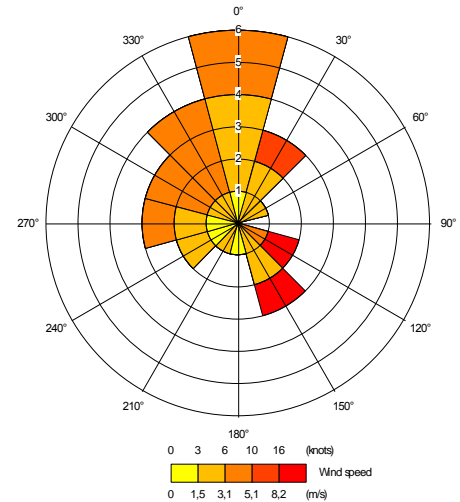

Fig. 6 Wind rose - June

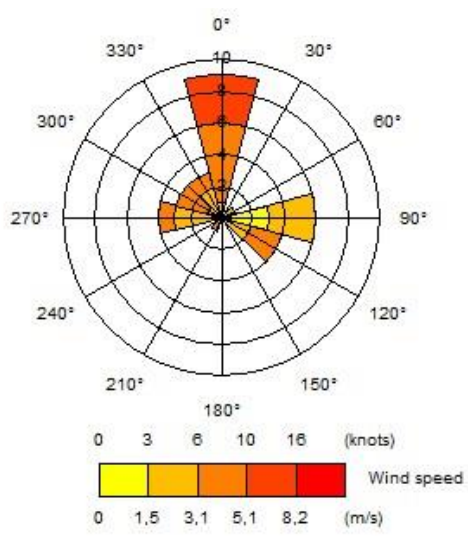

Fig. 7 Wind rose -July

\subsection{Dispersion modelling and estimation of the $\mathrm{NO}_{2}$ concentration levels}

After defining the micro-environment of the model, as well as other necessary input parameters, the simulation of $\mathrm{NO}_{2}$ dispersion during each month was performed separately.

The ADMS urban software can create short-term (daily and monthly) and long-term (annual) dispersion scenarios, as well as concentrations of pollutants at different altitudes in relation to land surface and different distances from the pollution sources.

Given the fact that one of the goals of this research paper is the assessment of traffic impact on the air quality as well as the potential population exposure, a concentration of $0-2 \mathrm{~m}$ above the land surface was analyzed (an altitude at which people are exposed to pollutants and their impact)

In all four cases of meteorological conditions, the $\mathrm{NO}_{2}$ concentrations obtained by modelling were relatively equal and ranged from $1.6 \mu \mathrm{g} / \mathrm{m}^{3}$ to $39.69 \mu \mathrm{g} / \mathrm{m}^{3}$. The maximum modelled concentration for all three sources obtained during the observed period was $39,69 \mu \mathrm{g} / \mathrm{m}^{3}$ and it was noted at the height of the source of pollutant. Modelled $\mathrm{NO}_{2}$ concentration levels are relatively low in comparison to defined one-hour limit values for $\mathrm{NO}_{2}$ (Table 1).

The statistical data analysis of the modelled $\mathrm{NO}_{2}$ concentration levels showed that $2,42 \mu \mathrm{g} / \mathrm{m} 3$ resulted in $98 \%$ of all cases and that it could be concluded that $\mathrm{NO}_{2}$ ambient concentrations originating from traffic within this part of the road and its surrounding are extremely low.

However, due to a slight road elevation, the concentration levels are different for each segment. The first segment of the road is at the ground level $(0 \mathrm{~m})$, so the highest $\mathrm{NO}_{2}$ concentration is found at the source itself i.e. at the emission level. 


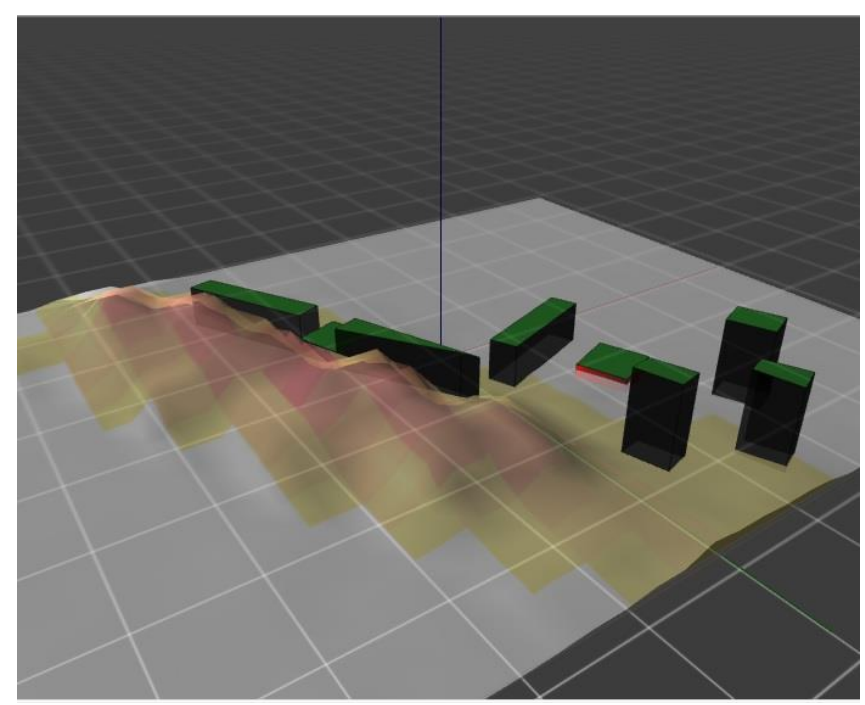

Fig. 8 Total concentration of $\mathrm{NO}_{2}$ from all sources

By analyzing each segment of the road, the maximum concentration is noted at the pollutant source itself that is found at 0,2 and $5 \mathrm{~m}$ (Figure 8). Due to elevation effect, the heights of maximum concentrations were changed (Figures 9 and 10).

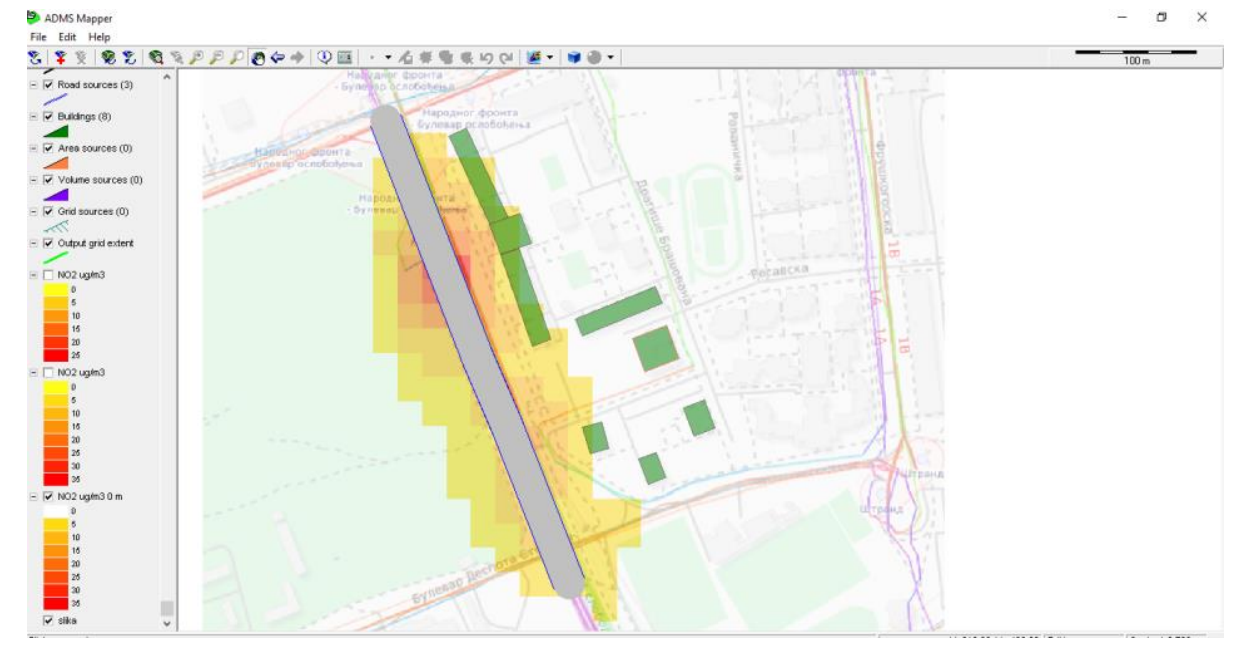

Fig. $9 \mathrm{NO}_{2}$ concentration $(0 \mathrm{~m})$ 


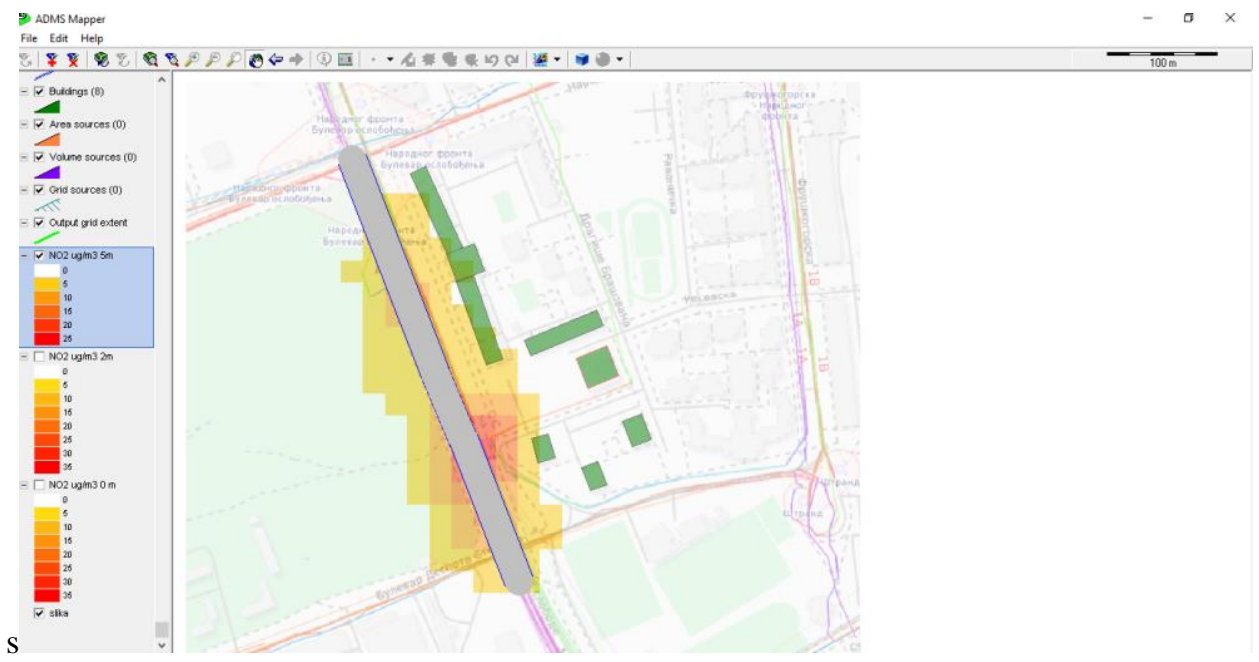

Fig.10 $\mathrm{NO}_{2}$ concentration $(2 \mathrm{~m})$

In this case, due to the elevation of the road, the impact on the observed facility (kindergarten) is minimal because the maximum $\mathrm{NO}_{2}$ concentration levels are found at the source level, which means that the most important amount of $\mathrm{NO}_{2}$ is emitted at the height of 2-5 meters.

\section{CONCLUSION}

This research paper shows modelled $\mathrm{NO}_{2}$ concentrations obtained by dispersion simulation after the emission of exhaust gases from vehicles. The case study covered a busy road segment near preschool facility on a bridge in the urban area of Novi Sad with the goal to identify $\mathrm{NO}_{2}$ concentration levels and the impact it has on vulnerable facility located nearby the road.

By $\mathrm{NO}_{2}$ dispersion simulation it was determined that modelled concentration levels did not exceed the limit values for the defined emission level and measured traffic flow. Additionally, meteorological conditions that are dominant when children are in the yard, as well as the bridge elevation effect, significantly contribute to the fact that $\mathrm{NO}_{2}$ concentration within the yard area and ground level is lower, so the potential impact is reduced as well.

The obtained results can serve as a starting point for preliminary monitoring of concentrations of pollutants in ambient air, i.e. establishment of a measuring station in accordance with the dominant meteorological conditions, as well as planned construction and regulation of urban areas. 


\section{REFERENCES}

1. Colvile, R.N., Hutchinson, E:J., Mindell, J.S., Warren, R.F., 2001. The transport sector as a source of air pollution. Atmos. Environ. 35, 1537-1565

2. Weichenthal, S., Farrell, W., Goldberg, M., Joseph, L., Hatzopoulou, M., 2014. Characterizing the impact of traffic and the built environment on near-road ultrafine particle and black carbon concentrations. Environ. Res. 132, 305e310.

3. European Environment Agency (2014). Nitrogen oxides (NOx) emissions (https://www.eea.europa.eu/downloads/f706b3a1315144cf85f4090a28f434f2/1441389609/assessment.2 010-08-19.0140149032-3.pdf (19.09.2017.)

4. [Seńczuk W . Niemetale i ich połączenia nieorganiczne. In:S eńczuk W . Toksykologia. Wydanie IV . Wydawnictwo Lekar-s kie PZWL. Warszawa 2002

5. Directive 2009/30/EC of the European Parliament and of the Council of 23 April 2009 amending Directive 98/70/EC as regards the specification of petrol, diesel and gas-oil and introducing a mechanism to monitor and reduce greenhouse gas emissions and amending Council Directive 1999/32/EC as regards the specification of fuel used by inland waterway vessels and repealing Directive 93/12/EEC (Text with EEA relevance)

6. Tallis M., Taylor, G., Sinnett, D., Freer-Smith, P., 2011. Estimating the removal of atmospheric particulate pollution by the urban tree conopy of London, Under current and future environment. Landscape and Urban Planning 103 (2), 129-138

7. Barnes, M., Brade, T., MacKenzie, R., Whyatt, D., Carruthers, D., Stocker. J., Cai., X., Hewitt, N. Enhanced „Urban Breathability , leads to deterioration in ground-level air-Quality.

8. Tallis M., Taylor, G., Sinnett, D., Freer-Smith, P., 2011. Estimating the removal of atmomspheric particulate pollution by the urban tree conopy of London, Under current and future environment. Landscape and Urban Planning 103 (2), 129-138

9. Wania, A., Bruce, M., Blond, N., Weber, C., Analysing the influence of different street vegetation on traffic-induced particle dispersion using microscale simulations, Journal of Environmental Management, 94, (2012), 91-101.

10. Wai-Yin Ng, Chi-Kwan Chau, A modeling investigation of the impact of street building configurations on personal air pollutio exposure in isolated deep urban canyons. Science of the totoal environment 468469 (2014), 429-448.

11. Senate Department for Urban development and Development (2014). Air Quality Plan for Berlin 20112017. (11.11.2017.) (https://www.berlin.de/senuvk/umwelt/luftqualitaet/de/luftreinhalteplan/download/lrp_150310_en.pdf

12. Uredba o uslovima za monitoring i zahtevima kvaliteta vazduha ("Sl. Glasnik rs", br, 11/2010)

13. Health Aspects of Air Pollution with Particulate Matter Ozone and Nitrogen Doixide Report on a WHO Workong Group, 2003, Bonn, Germany.

14. Bylow on air quality monitoring requirements (Official Gazette RS No11/10)

15. United States Environmental Agency, www. usepa.gov

16. CERC, 2001. ADMS-Urban: Urban Air Quality Management System. User Guide. Version 3.1. CERC Limited, Cambridge, (www.cerc.co.uk.), (14.09.2017.)

17. GIS Novi Sad http://www.mapanovisad.rs/mapserver2015/nsmaps/ (26.11.2015.)

18. Meteorological yearbook- climatological data 2016, www. hidmet.gov.rs (8.09.2017.) 


\section{UTICAJ DINAMIKE SAOBRAĆAJA NA KVALITET AMBIJENTALNOG VAZDUHA I VULNERABILNE OBJEKTE U OKOLINI PROMETNE SAOBRAĆAJNICE U NOVOM SADU}

U radu je izvršena simulacija rasprostiranja azot-dioksida poreklom iz vozila sa prometne saobraćajnice u Novom Sadu koja se nalazi u neposrednoj blizini stambenih zgrada $i$ vrtića. Na osnovu proračunatog stepena emisije azot-dioksida iz vozila, kao i najučestalijih meteoroloških uslova izvršena je simulacija rasprostiranja azot-dioksida upotrebom softverskog paketa ADMS urban. S obzirom na to da je predmetni segment saobraćajnice deo mosta čija se elevacija postepeno povećava uutvrđeno je da je izloženost pojedinih delova stambenih zgrada konstatntna $i$ intezivna. Rezultati prikazani u ovom radu mogu poslužiti kao polzna osnova za preduzimanje konkretnim mera u cilju smanjanja uticaja saobraćaja na kvalitet vazduha $i$ zdravlje ljudi, kroz urbano planiranje naročito vulnerabilnih objekata. Abstract in Serbian (9pt, 0,5 cm, special first line $0,5 \mathrm{~cm}$, justified).

Ključne reči: urbana sredina, kvalite vazduha, modelovanje emisije iz saobraćaja 